\title{
TECTAM: An Approach to Study Technology Acceptance Model (TAM) in Gaining Knowledge on the Adoption and Use of E-Commerce/ E-Business Technology among Small and Medium Enterprises in Thailand
}

\author{
Vasin Chooprayoon ${ }^{1}$ and Chun Che Fung ${ }^{2}$ \\ ${ }^{1}$ School of Information Technology, Rangsit University, Thailand \\ ${ }^{2}$ School of Information Technology, Murdoch University, Australia
}

\section{Introduction}

One of the four pillars of knowledge management according to Stankosky (2000), Calabrese (2000) and Baldanza \& Stankosky (2000) is the technology pillar. It is important to study knowledge management $(\mathrm{KM})$ based on this pillar in diverse dimensions. The technology pillar consists of a number of disciplines including computer science, computation mathematics, operation research, electrical engineering, mathematics/statistics, and logic. Moreover, data warehousing, database management, multimedia repositories, groupware, decision support system, expert systems, corporate Intranet, business modeling systems, etc. are also representative key sub-elements defining this pillar (Calabrese, 2005). In another aspect of KM, gathering, using and sharing knowledge are executed by Information and Communication Technology (ICT) implemented as a Knowledge Management System (KMS). ICT can facilitate and integrate knowledge among businesses that have adopted ICT to run their business processes. It is reasonable to mention that this pillar concerns with a range of studies on innovation adoption based on a variety of aspects. Gaining knowledge on the adoption and use of e-commerce/e-business technology based on KM concept would be expected to be conducted by using the proposed approach, TECTAM which is presented in this chapter.

In the studies of the adoption of information systems/technology, Technology Acceptance Model (TAM) is one of the most dominant research models which have been used widely. TAM composes of two key determinants: perceived usefulness (PU) and perceived ease of use (PEOU). In this study, these factors are hypothesized to be the essential basis for verifying user acceptance of e-commerce/e-business technology in Thailand based within the context of KM practices. This chapter reviews the TAM concepts and proposes an approach to modify the TAM for investigating and gaining knowledge on how small and medium enterprises (SMEs) in Thailand adopt e-commerce technology (ECT). The rapid growth of ICT in Thailand has made user acceptance an increasingly critical issue in 
technology implementation and management. PU and PEOU of Thai public organisations, SMEs, and online customers are investigated in this study to predict the Thai SMEs' adoption and use ECT.

\section{E-Commerce Technology Adoption by SMEs in Thailand}

In 2000, the Thai government released the SMEs Act for promoting and developing SMEs in Thailand. In the meantime, the Office of Small and Medium Enterprises Promotion (OSMEP), the Institute for Small and Medium Enterprises Development (ISMED), and the Small and Medium Enterprise Development Bank of Thailand were also founded in order to contribute towards the development of Thai SMEs for elevating them to the global commercial scene. There are three key platforms or vehicles in the Thai government's SMEs promotion policy: a) investment promotion, b) financial assistance, and c) technical and management consultancy (OSMEP, 2001a; OSMEP, 2001b).

It is recongnised that the predominant factors influence the achievement of the e-commerce adoption and use are: ICT groundwork, government planning and policy, payment systems, taxation, law concerning e-commerce transactions, data protection, consumer protection, intellectual property rights, e-commerce security and safety, efficient transportation, and people recognition (ECRC, 2000; OSMEP, 2001a). Furthermore, in the Thailand Vision towards a Knowledge-Based Economy (IT 2010) document, it points out that ICT is an enabler to increase business productivity and capacity for business competition (NITC, 2002). However, the e-commerce adoption and use of Thai SMEs are currently in a state of early growth. Most of the entrepreneurs who use e-commerce strategy for competitive advantages are still mainly within the hospitality businesses, and a relatively small portion in the trade and retailing sector. In summary, Thai SMEs' lack of e-commerce innovation is mainly due to their limitation of resources in terms of budget and e-commerce knowledgeable personnel (OSMEP, 2001b).

Thailand Investor Service Centre (TISC, 2006) pointed out that the important and long term policies of the Thai government should be: construction of ICT network to support the production factor; developing worldwide marketing strategies; encouraging SMEs to do business in e-commerce, and, establishing channels of communication among industries in the capital and regional areas. Thailand, which now has two categories of Internet Service Providers (ISPs). This comprises of twenty-one commercial ISPs and four non-commercial Internet hubs. Two Internet exchanges have already been set up:

a) The ThaiSarn Public Internet Exchange (PIE) is a peering point for Thai ISPs to access public information on the ThaiSarn Public Access Network (PubNet) operated by the Network Technology Laboratory (NTL) of the National Electronics and Computer Technology Center (NECTEC).

b) Communication Authority of Thailand (CAT) - National Internet Exchange (CAT-NIX) has two sectors: International Internet Gateway (IIG)which is the Internet gateway of Thailand connecting Thai ISPs to the global networks, and, NIX, is the national exchange among all ISPs in Thailand providing exchange for the domestic traffics.

Furthermore, to date, Thai domain names which are registered under '.th' have registered a total of 42,194 domain names in which the 20,392 of them are '.co.th'. This amount is about $48.3 \%$ of the total number of Thai domain names. This ratio indicates the growth of online business. The growth rate of '.co.th' during 2000-2009 has exceeded more than 400\%( 
NECTEC, 2009a). The rate of increase for the Internet users in Thailand since 2000has also indicated a constant strong growth. This has provided ample opportunities for the Thai population to access information resources worldwide, and they are able to carry out online shopping or carry out business operations through e-commerce ( NECTEC, 2009b).

\section{Technology Acceptance Model (TAM)}

TAM is adapted from the Theory of Reasoned Action (TRA) model which describes human behaviours in a specific situation (Fishbein \& Ajzen, 1975). TRA proposes that a person's behaviour is determined by the person's intention to perform the behaviour; and the 'intention' is a function of the person's attitude toward the behaviour and subjective norms. Therefore, 'intention' is the best predictor because it cognitively represents a person's readiness to perform certain behaviour which is antecedent. 'Intention' is determined by three factors: attitude towards the specific behaviour, subjective norms, and perceived behavioural control (Ajzen, 2002).

The main purpose of TAM is to present an approach to study the effects of external variables towards people's internal beliefs, attitudes, and intentions. TAM proposes the perceived ease of use (PEOU) and perceived usefulness (PU) as the most important factors for explicating technology acceptance. Davis (1989) and Davis, Bagozzi \& Warshaw (1989) pointed out that external variables such as direct experiences, objective usability, and self efficacy intervene indirectly to PEOU and PU (in TAM), attitude, and subjective norms (in TRA). Furthermore, Davis (1989) used methods of Fishbein \& Ajzen (1975) for assessing the users' Attitude Towards using (AT) and Behavioural Intention to use (BI). However, subject norms were excluded because of their slight effect on BI. On the other hand, Venkatesh and Davis (2000) reconsidered the influence of subjective norms to people behaviour and found that the subject norms have effects towards the behaviour. Venkatesh and Morris (2000) used the proposed model to analyse how some factors such as gender and experience also influence the intention to use information systems.

In summary, TAM has developed and evolved continually over the years. It has verified and confirmed by many scholars as a practical theoretical model for the investigation of users' behaviour. In this chapter, it is therefore utilized to study the acceptance of ECT by the Thai SMEs based on the notion of knowledge management within the Thai SMEs context.

\section{Relationship between TAM and Other Models}

Although TAM has been verified by scholars worldwide, combining TAM with other theoretical models is more useful for investigating the technological acceptance by users. For example, attitude toward behaviour (AI) and subject norms from the TRA model are used by Davis (1989) in conjunction with TAM to clarify how the subjective norms affect technology adoption and acceptance. Taylor \& Todd (1995) combined three core constructs from the Theory of Planned Behaviour (TPB) with TAM to develop a hybrid model for investigating technological acceptance. The three core constructs are: attitude towards behaviour, subjective norm, and perceived behavioural control. Rogers (1995) proposed a five stage model for the innovation decision process. The five stages are: knowledge, persuasion, decision, implementation, and confirmation. Subsequently, the model was 
applied to study an individual decision making process of whether to adopt or reject innovation in TAM context (Wymer \& Regan, 2005; Kiraz \& Ozdemir, 2006).

TAM is also linked to the Task-Technology Fit Model (TTF).The core concept of TTF is how to measure the ability of information technology to support organisation tasks (Goodhue \& Thompson, 1995). Four main constructs of TTF model are: task characteristics, technology characteristics, task-technology fit, and utilization or performance. These constructs are inter-related to each other. The TTF and TAM have recently been combined to predict ecommerce adoption by consumers (Klopping \& McKinney, 2004). Dishaw and Strong (1999) extended the TAM with the TTF to workplace technology adoption. Zigurs et al. (1999) used TAM-TTF to predict group decision support system acceptance.

Vankatesh et al. (2003) developed the Unified Theory of Acceptance and Use of Technology (UTAUT) which formulates, integrates and broadens further than the TAM. UTAUT is a new theory which combines eight theories together: TRA, TAM, MM (Motivational Model), TPB, TAM-TPB, MPCU (Model of PC Utilization), IDT (Innovation Diffusion Theory, and SCT (Social Cognitive Theory). The UTAUT consists of four key determinants of intention and usage: performance expectancy, effort expectancy, social influence, and facilitating conditions. Furthermore, the variables of gender, age, experience and voluntariness of use moderate the relationship in the model (Vankatesh et al., 2003). Anderson \& Schwager (2003) used the UTAUT for investigating wireless LAN technology adopted by SMEs.

In a similar fashion, the proposed model in this chapter is based on TAM and extended with variables which have been proposed in models such as TRA, TRP, UTAUT and TTF. It is expected that the extended model will be able to provide a comprehensive framework to identify the influencing factors for ECT adoption and use by SMEs in Thailand. The model is described in the next section.

\section{TECTAM-Thai E-Commerce Technology Acceptance Model}

This chapter aims to propose a model based on TAM to investigate ECT acceptance and adoption by Thai SMEs and related stakeholders. A number of previous predominant TAM research reports have been reviewed in order to establish the appropriate variables, research tools, methodologies and how to apply them to the context of this study. The TECTAM model is developed and proposed as shown in Figure 1. The model is largely based on TAM theory and it is believed that it is appropriate for the investigation of ECT acceptance and adoption by SMEs in Thailand. 


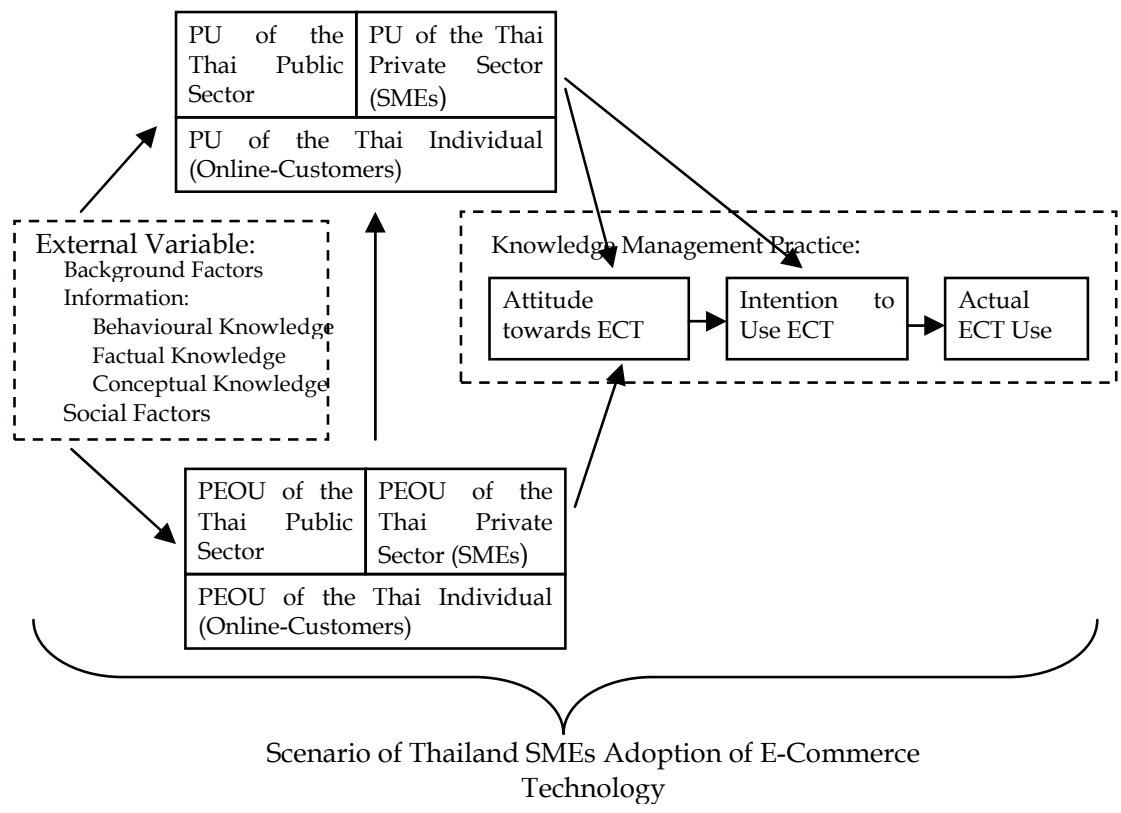

Fig. 1. TECTAM Model for Assessing the Adoption of ECT by Thailand SMEs

Three types of questionnaires are developed for gathering data from SMEs, online customers, and related government organisations and institutions. Background factors of respondents are design based on Ajzen (2005)'s notion. They are: personal factors (general attitudes, personality traits, values, emotions, and intelligences), social factors (age, gender, education, and income), and information (experience, knowledge, and media exposure). Moreover, three types of knowledge (Bunge, 1979) are designed as part of the external variables. In the context of this study, the knowledge is referred to:

a) Behavioral Knowledge which is the knowledge of Thai public sector, SMEs, and onlinecustomers concerning with how to do, what to do, and what action to undertake about ECT.

b) Factual Knowledge which is the knowledge of Thai public sector, SMEs, and onlinecustomers about information and events related to ECT.

c) Conceptual Knowledge which is the knowledge of Thai public sector, SMEs, and online-customers on high level abstract concept, ideals and judgments about ECT.

The validation and evaluation of TECTAM will be based on survey and interviews. The construction of questionnaires and interview questions are derived from Ajzen \& Fishbein (1980), Davis et al. (1989), Legris et al. (2003), Venkatesh et al. (2003). Data will be collected and analysed to prove the following hypotheses:

- PU of the public sector, SMEs, and online customer are positively related to attitude towards ECT

- PU of the public sector, SMEs, and online customer are positively related to intention to use ECT

- PEOU of the public sector, SMEs, and online customer are positively related to PU 
- PEOU of the public sector, SMEs, and online customer are positively related to attitude towards ECT

- Attitude towards ECT of the public sector, SMEs, and online customer are positively related to intention to use ECT

- Intention to use ECT the public sector, SMEs, and online customer are positively related to actual ECT use

- External variables of the public sector, SMEs, and online customer are positively related to PU

- External variables of the public sector, SMEs, and online customer are positively related to PEOU

Finally, methodologies for the study are a) field study by questionnaire survey; b) the Multiple Regression which will be used for measuring the eight hypotheses.

\section{Conclusion}

A proposed model based on TAM theory in this paper integrates three sectors involved with SMEs in Thailand. Much of the previous research on ECT adoption has focused on individual and separate sectors. It is difficult to assess the effects of ECT adoption from a country's perspective. In this chapter, it is intended to emphasise an integrated model comprising all these sectors and to explore the situation of ECT adoption by Thai SMEs in holistic approach. It is expected that the outcomes from the study using TECTAM will not only produce a report card on the current situation, but also provide appropriate suggestions to the relevant stakeholders on the policies and steps of ECT development and promotion to be taken. It is anticipated that such measures will promote the adoption of ECT and contribute to Thailand's economy.

\section{References}

Ajzen, I. (2005). Attitudes, Personality and Behavior, 2d ed., Open University Press, ISBN0335217044, Berkshire, England

Ajzen, I. \& Fishbein, M. (1980). Understanding Attitudes and Predicting Social Behaviour, Prentice-Hall, ISBN- 0139364358, Englewood Cliffs, NJ

Anderson, J. \& Schwager, P. (2003). “SME Adoption of Wireless LAN Technology: Applying the UTAUT Model," Proceedings of the 7th Conference of the Southern Association for Information Systems, Savannah, Georgia, pp.39-43 [Online] [cited 24th April 2009]. Available from http:/ / sais.aisnet.org/sais2004/Anderson\%20\&\%20Schwager.pdf

Baldanza, C. \& Stankosky, M. (2000). "Knowledge Management: an Evolutionary Architecture toward Enterprise Engineering," pp. 13.2-1 - 13.2-8, International Council on System Engineering (INCOSE), May, 2000, Reston, VA

Benford, T. L. \& Hunton, J. E. (2000). “Incorporating Information technology Considerations into an Expanded Model of Judgment and Decision Making in Accounting," International Journal of Accounting Information Systems, Vol. 1, No. 1, pp. 54-65, ISSN: 1467-0895

Bunge, M. (1979). Treatise on Basic Philosophy: Vol.4: Ontology II: A World of Systems, D. Reidel Publishing Company, ISBN: 978-90-277-0944-8, Netherland 
Calabrese, F. A. (2000). "A Suggested Framework of Key Elements Defining Effective EnterpriseWide Management Programs," Doctoral Dissertation, George Washington University, Washington, D.C.

Calabrese, F. A. (2005). “The Early Pathways: Theory to Practice a Continuum," In Creating the Discipline of Knowledge Management: the Latest in University Research, Michael Stankosky (Ed.), pp. 15-50, Elsevier Inc., ISBN-13: 978-0-7506-7878-0, Amsterdam

Davis, F. D. (1989). "Perceived Usefulness, Perceived Ease of Use, and User Acceptance of Information Technology," MIS Quarterly, Vol. 13, No. 3, September 1989, pp. 319339, ISSN- 0276-7783

Davis, F. D.; Bagozzi, R. P. \& Warshaw, P. R. (1989). “User Acceptance of Computer Technology: A Comparison of Two Theoretical Models," Management Science, Vol. 35, No. 8, August 1989, pp. 982-1003, ISSN- 0025-1909

Dishaw, M. T. \& Strong, D. M. (1999). "Extending the Technology Acceptance Model with Task-Technology Fit Constructs," Information and Management, Vol. 36, No.1, July 1999, pp. 9-21, ISSN- 0378-7206

ECRC (Electronic Commerce Resource Centre). (2000). “National Electronic Commerce Policy Framework," [Online], [Cited 28 March 2006], International Workshop on Electronic Commerce Policy and Regional Cooperation, "Digital Economy for Communities and SMEs Development" 19 - 21 June, 2002, Bangkok, Thailand, Available from: http://www.ecommerce.or.th/APEC-Workshop2002/ppt/pdf/ thailand_ecframeworkEng.pdf

Fishbein, M. \& Ajzen, I. (1975). Belief Attitude, Intension and Behaviour: An Introduction to Theory and Research, Addison-Wesley, ISBN- 0201020890, Reading, MA

Goodhue, D. L. \& Thompson, R. L. (1995). “Task-Technology Fit and Individual Performance," MIS Quarterly, Vol. 19, No. 2, June 1995, pp. 213-236, ISSN-0276-7783

Kiraz, E. \& Ozdemir, D. (2006). "The Relationship between Educational Ideologies and Technology Acceptance in Pre-Service Teachers," Educational Technology \& Society, Vol. 9, No. 2, pp. 152-165, ISSN- 1176-3647 1436-4522

Klopping, I. M. \& Mckinney, E. I. (2004). “Extending the Technology Acceptance Model and the Task-Technology Fit Model to Consumer E-Commerce." Information Technology, Learning, and Performance Journal, Vol. 22, No. 1, Spring 2004, pp.35-48, ISSN- 15351556 0737-8998 1

Legris, P., Ingham, J. \& Collerette, P. (2003). “Why Do People Use Information Technology? A Critical Review of the Technology Acceptance Model," Information $\mathcal{E}$ Management, Vol. 40, No. 3, January 2003, pp. 191-204, ISSN- 0378-7206

Moore, G. C. \& Benbasat, I. (1991). “Development of an Instrument to Measure the Perceptions of Adopting an Information Technology Innovation," Information Systems Research, Vol., 2, No. 3, March 1991, pp. 192-222, ISSN- 1526-5536

NECTEC (National Electronics and Computer Technology Centre), Internet Information Research. (2009a). Domain under.TH, [Online], [Cited 24th April 2009], Available from http:/ / internet.nectec.or.th/webstats/domainth.iir?Sec=domain_th

NECTEC (National Electronics and Computer Technology Centre), Internet Information Research. (2009b). Internet User in Thailand, [Online], [Cited 24th April 2009], Available from http://internet.nectec.or.th/webstats/internetuser0.iir?Sec= internetuser 
NITC (National Information Technology Committee Secretariat). (2002). Thailand Vision towards a Knowledge-Based Economy (IT 2010), NECTEC, ISBN 974-229-226-4, Bangkok

OSMEP (The Office of Small and Medium Enterprise Promotion). (2001a). "Overview and Trends of SMEs (White Paper on Small and Medium Enterprises 2001)," [Online], [Cited 23 August 2006], Available from http://www.sme.go.th/websme/ download/ch2_eng_2001.pdf\#search=\%22a\%20number\%20of $\% 20$ SMEs $\% 20 \mathrm{in} \% 20 \mathrm{~T}$ hailand $\% 22$

OSMEP (The Office of Small and Medium Enterprise Promotion). (2001b). "SMEs and the eCommerce," [Online], [Cited 12 August 2006], Available from http://www.sme.go.th/websme/smeeng/Knowledge

/Marketing_SMEs\%20and\%20the\%20e-Commerceedge.html

OSMEP (The Office of Small and Medium Enterprises Promotion). (2002). "The Summary of Action Plan for Thai SMEs Promotion in 2002-2006," [Online], [Cited 30 March 2006], Available from http://www.sme.go.th/file.aspx?action=download\&cid=283778\% 20

Rogers, E.V. (1995). Diffusion of Innovations, 4th ed., The Free Press, ISBN- 0029266718, New York

Stankosky, Michael A. (2000). "A Theoretical Framework," KM World, Vol. 9, No. 1, January2000

Taylor, S. \& Todd, P.A. (1995). “Assessing IT Usage: the Role of Prior Experience," MIS Quarterly, Vol. 19, No. 2, June 1995, pp. 561-570, ISSN- 0276-7783

TISC (Thailand Investor Service Centre). (2006). "SMEs Policy," [Online], [Cited 16 November 2006], Available from http://www.thailandoutlook.com/ thailandoutlook1/govrnment+policy/Government+policy+Update/SMEs+Policy. htm

Venkatesh, V. \& Davis, F.D. (2000). “A Theoretical Extension of the Technology Acceptance Model: Four Longitudinal Field Studies," Management Science, Vol. 46, No. 2, February 2000, pp. 186-204, ISSN- 0025-1909

Venkatesh, V. \& Morris, M. G. (2000). “Why Do Not Men Ever Stop to Ask for Directions? Gender, Social Influence, and Their Role in Technology Acceptance and Usage Behavior," MIS Quarterly, Vol. 24, No. 1, March 2000, pp. 115-139, ISSN- 0276-7783

Venkatesh, V., Morris, M. G., Davis, G. B. \& Davis, F. D. (2003). “User Acceptance of Information Technology: Toward a Unified View," MIS Quarterly, Vol. 27, No. 3, September 2003, pp. 425-478, ISSN- 0276-7783

Wymer, S. A. \& Regan, E. (2005). "Factors Influencing E-Commerce Adoption and Use by Small and Medium Businesses," Electronic Markets, Vol. 15, No. 4, November 2005, pp. 438-453, ISSN- 1019-6781

Zigurs, I., Buckland, B. K., Connolly, J. R. \& Wilson, E. V. (1999). “A Test of Task-Technology Fit Theory for Group Support Systems," ACM SIGMIS Database, Vol. 30, No. 3-4, Summer-Fall 1999, pp. 34-50, ISSN- 1532-0936 0095-0033 


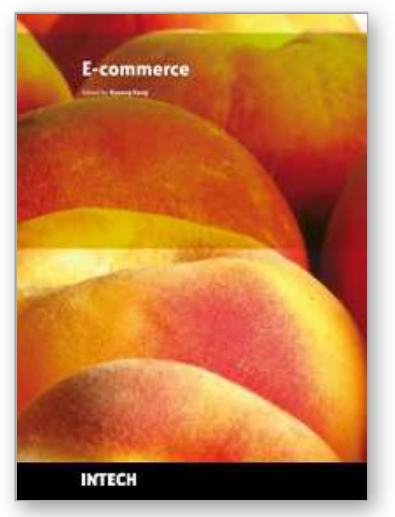

\author{
E-commerce \\ Edited by Kyeong Kang
}

ISBN 978-953-7619-98-5

Hard cover, 284 pages

Publisher InTech

Published online 01, February, 2010

Published in print edition February, 2010

E-commerce provides immense capability for connectivity through buying and selling activities all over the world. During the last two decades new concepts of business have evolved due to popularity of the Internet, providing new business opportunities for commercial organisations and they are being further influenced by user activities of newer applications of the Internet. Business transactions are made possible through a combination of secure data processing, networking technologies and interactivity functions. Business models are also subjected to continuous external forces of technological evolution, innovative solutions derived through competition, creation of legal boundaries through legislation and social change. The main purpose of this book is to provide the reader with a familiarity of the web based e-commerce environment and position them to deal confidently with a competitive global business environment. The book contains a numbers of case studies providing the reader with different perspectives in interface design, technology usage, quality measurement and performance aspects of developing web-based e-commerce.

\title{
How to reference
}

In order to correctly reference this scholarly work, feel free to copy and paste the following:

Vasin Chooprayoon and Chun Che Fung (2010). TECTAM: An Approach to Study Technology Acceptance Model (TAM) in Gaining Knowledge on the Adoption and Use of E-Commerce/E-Business Technology among Small and Medium Enterprises in Thailand, E-commerce, Kyeong Kang (Ed.), ISBN: 978-953-7619-98-5, InTech, Available from: http://www.intechopen.com/books/e-commerce/tectam-an-approach-to-studytechnology-acceptance-model-tam-in-gaining-knowledge-on-the-adoption-and

\section{INTECH}

open science | open minds

\section{InTech Europe}

University Campus STeP Ri

Slavka Krautzeka 83/A

51000 Rijeka, Croatia

Phone: +385 (51) 770447

Fax: +385 (51) 686166

www.intechopen.com

\section{InTech China}

Unit 405, Office Block, Hotel Equatorial Shanghai

No.65, Yan An Road (West), Shanghai, 200040, China 中国上海市延安西路65号上海国际贵都大饭店办公楼 405 单元

Phone: +86-21-62489820

Fax: $+86-21-62489821$ 
(C) 2010 The Author(s). Licensee IntechOpen. This chapter is distributed under the terms of the Creative Commons Attribution-NonCommercialShareAlike-3.0 License, which permits use, distribution and reproduction for non-commercial purposes, provided the original is properly cited and derivative works building on this content are distributed under the same license. 